\title{
A CRITICAL REFLECTION ON THE CHRISTIAN TEACHING ON POLYGAMY IN RELATION TO ITS EFFECT ON THE AFRICAN SOCIETY
}

\author{
Peter Bisong Bisong ${ }^{1}$, Modestus Ogonna Orji ${ }^{2}$ \\ ${ }^{1}$ Department of Philosohy, University of Calabar, Nigeria. \\ pbbisong@yahoo.com ${ }^{1}$ \\ ${ }^{2}$ Department of General Studies, Federal College of Agriculture, \\ Ishiagu, Ebonyi state, Nigeria.
}

\begin{abstract}
The early Christian missionaries have been scathingly accused of uprooting Africans from their historical past and for failing to incorporate African traditional values into Christianity. One of such African traditional values that were booted away by Christianity, is polygamy. Africa is known to have been polygamous but was forced to drop this in favour of Christian monogamy. This paper x-rayed the impact of the Christian doctrine on polygamy on African society and concludes that the practice produces more dysfunctional effects than functional ones. It, therefore, advises the church to revise the one man, one wife doctrine. At best, it should be made optional
\end{abstract}

Keywords: Polygamy, African societies, Christian Teaching, Marriage.

\section{INTRODUCTION}

It is difficult to imagine a lady of 30 years of age (who is ready for marriage) in traditional African societies not having a husband (Omoregbe 1979). Cases of promiscuity, abortion, prolonged singlehood, infertility, increasing cost of weddings and high rate of divorce that are now prevalent today were either absent or minimal in traditional African societies. What could be the reason for the upsurge of these problems?

We acknowledge the fact that it is difficult to point at one cause, but when we call to mind, the fact that the emergence of these problems coincides with the reign of Christianity, it becomes easy to apportion blame. The fact that these issues are more in Christian populated areas of the society than the Muslim populated areas lay more credence to the idea that Christianity, directly or indirectly has a share in the marital and other associated problems that are presently rocking Nigeria and Africa at large (Ojukwu 1995). The one-man one wife doctrine propagated by Christianity and which has taken root in almost all Christian societies may have served the cause of feminism well but has invariably led to delays in marriage in Africa and in most cases inability to marry at all. This has led to many disastrous effects in contemporary African societies.

This paper x-rays these dysfunctional effects of polygamy, with a view of helping the church see reasons, why she was wrong to negate polygamy in Africa. Polygamy served useful purposes in traditional Africa and its abolition is a curse rather than a blessing.

\section{THE CHURCH'S TEACHINGS ON POLYGAMY}

The understanding of polygamy in this work is that of one man taking up different wives. The Old Testament of the Christian bible seemed to have no problem with polygamy, as many men of God like Abraham, David, Solomon etc, were polygamous. However, the Christian church today preaches against it and demands a new convert to abhor it. The Catechism of the Catholic Church says: 
The predicament of a man who, desiring to convert to the Gospel, is obliged to repudiate one or more wives with whom he has shared years of conjugal life, is understandable. However, polygamy is not in accord with the moral law." [Conjugal] communion is radically contradicted by polygamy; this, in fact, directly negates the plan of God which was revealed from the beginning, because it is contrary to the equal personal dignity of men and women who in matrimony give themselves with a love that is total and therefore unique and exclusive.

The church teaches that polygamy was not the original plan of God for man, He only allowed it in the Old Testament but did not command it. His original plan for marriage according to the church is found in Genesis. 2:27-28, which reads:

So God created man in his own image, in the image of God he created him; male and female he created them. And God blessed them. And God said to them, "Be fruitful and multiply and fill the earth and subdue it and have dominion over the fish of the sea and over the birds of the heavens and over every living thing that moves on the earth.

Other scriptural passages often quoted to support monogamy include Matthew 19:3-9, 1.Corinthians 7:1-5. Titus 1:6 etc. While not rebutting the authenticity of this belief, I believe that if God allowed polygamy in the Old Testament, He would have no problem with Africans practicing it. He definitely has not changed, He is still the same as of old. Moreover, the church that allowed Gentile converts to practice Christianity without insisting that they pass through circumcision as was commanded in the bible, should also have allowed polygamy in Africa, considering the negative effects it stoppage will breed.

\section{NEGATIVE EFFECTS OF THE REJECTION OF POLYGAMY}

Rejection of polygamy by Christianity has a lot of negative effects on Africans and African societies. The most important effects include:

Increases the number of unmarried Women: In the traditional African societies, where one was allowed to marry more than one wife, it is rationally implausible that one could think of a case where a woman would remain unmarried at the age of 30. Gyekye puts it well when he asserts that "women in African societies want and hope to be married; in fact, an unmarried woman is almost an anomaly. Marriage is a requirement of the society, an obligation every man and woman must fulfill, a drama of life in which every man and woman must participate" (1996:76). The church move, against polygamy in Africa, has led to a pathetic situation, whereby unmarried women are scattered all over the streets. Most of these unmarried women, out of desperation get involved in so many unholy activities like getting charms to attract men, husband snatching, performing rituals and sacrifices, etc., (Kiyimba 2011). Aside from desperation, most of these unmarried women experience shame, reproach, hopelessness, reduced self-esteem and other effects that come with being unmarried at a certain age. All these were not in existence in pre-Christian Africa (Edet $2003 ; 2018)$. And would not exist now, if polygamy was allowed.

Let's reflect on this carefully. Assuming in our society today, everybody is allowed to marry more than one wife and let's say each man marries two wives. Will they be any girl of the age of marriage, who will not be married? We seriously do not think so. No matter how ugly a girl maybe, she will at least find somebody who would make her his 
second, third, or fourth wife. When this is the case, there will be practically no girl that will not find herself in a man's house, which implies that this could wipe out the scourge, torments, trauma, desperation, insecurity, evil that comes with not being married. It would also boost the economic productivity of the nations, for a relaxed and untroubled mind is a productive mind.

\section{REJECTION OF POLYGAMY INCREASES IMMORALITY}

Polygamy to me has not gone away from contemporary Christian societies; it has merely assumed another form (Rongjian 2017). A more dangerous form. The former form was legitimate and thus accepted by the society, the later illegitimate and condemned, but still hold sway with no sign that it will ever go away. Christianity only succeeded in driving away from a legitimate form of life and paved the way for the emergence of an illegitimate one. To put it in better parlance, it converted a once legitimate lifestyle into an illegitimate one, without actually succeeding in transforming the people, as they still indulge in this legitimate lifestyle now turned illegitimate en masse. Before the advent of Christianity, a married man will go ahead and marry a woman he loves as either his second, third, or fourth wife. But with the coming of Christianity, instead of legitimately marrying the woman he loves, he sneaks out in the night to have sexual relations with her, thereby increasing crisis, sexual promiscuity in the society and putting himself in danger of ending in the fearful hellfire of the Christian belief. By preaching against polygamy, Christianity unwittingly made way for the increase of the greater evil (sexual promiscuity and the social problems that come with it).

To reject Polygamy is to go against Nature: African men, indeed all men, are by nature polygamous. The activities of feminism and Christianity have not been able to erase this nature. The women that the feminists and missionaries fought for, appear to me, to be in support of polygamy (Witte 2003). The women themselves fan the fire of polygamy; for without their acceptance, polygamy will not continue unofficially. Extramarital affairs are a result of an agreement between the man and the woman, showing that the women themselves that the feminists seemingly fight for, see nothing inherently wrong with polygamy. What then is the rationale in stopping it officially? Can nature actually be stopped? Nature arranged it in such a way that a man cannot be satisfied sexually by one woman. We acknowledge the existence of exception because in life there are exceptions in everything. Thus, the fact that few men are not by nature polygamous does not nullify the fact that men are by nature polygamous. A man is sexually active (except for unnatural reasons like sickness, stress) at all times.

A woman on the contrast in addition to these unnatural reasons that affect man is by nature not capable of sexual activity at all times. During her menstruation, heavy pregnancy, and a few weeks after childbirth, she may not be ready for sexual activities. A man forced to marry only one wife will be made to unnecessarily controlling his libido at these periods and in most cases, he fails, especially when his drives happen to be unfortunately high at the time the woman is naturally not ready. In addition to this, most times of her life, the woman is not sexually attractive, like when she is heavily pregnant. Is it right to expect the man to always go against his nature, by suppressing his natural desires at this period of the woman's life? What pastors and other feminists will always say is that the man should control himself at these periods. Yes, they are right, but he is not able, as the happenings in the society show. Since he is not able, he goes out in search of 
satisfaction outside and most times his family suffers, because of the cost this entails. If he was allowed to marry more than one wife, then at this period, he will not need to trouble the undisposed wife or commit 'sins'; he will only need to go to his next wife and get his satisfaction.

To reject Polygamy is to widen the gap between the Rich and the Poor in the Society: Polygamy was one way of life that ensured that in traditional Africa, nobody was too rich and nobody was too poor. The gap between the rich and the poor was narrowed by polygamy and communal living. Polygamy ensures that the wealth of a rich man circulates to other people. Through the marriage of many wives, a rich man circulates his wealth to others; at least his wives will be empowered, his in-laws will also be touched by the wealth and in the long run, the riches will circulate too many people. To marry one wife is to concentrate one's wealth on a single woman and her family, but marrying many wives will make more people benefit from the money and as such more people will be raised from poverty. This will make the rich man not to be too rich and others linked to him not to be too poor. In Africa, marriage is not between two individuals but between two families (Anna et al., 2020). Marriage, therefore, creates an obligation between two families. Monogamy reduces the dependants of a man, and as such is capable of making a man be so rich, while so many that will have been helped, if he had married more wives will remain in poverty, thereby widening the gap between the rich and the poor. Polygamy helped to close this gap. Let's imagine what will happen if all the rich men in Nigeria, marry more than one wife. The network of people whose lives will be touched by the men's wealth will increase, which means the number of very poor people will reduce, thereby reducing the gap between the rich and the poor.

Some people may argue that the gap between the rich and the poor can still be closed through the imbibing of the virtue of charity. Yes, the charity can serve to close this gap, but how do we make people charitable, Christianity and other religions have failed. The reality is that people today are more uncharitable than they were in the past, thanks to the fear imposed by preachers, that their charities could be turned against them by evil people. In polygamy, charity is not what brings forth help to the in-laws. The help that comes as a result of marriage is in a way obligatory. In traditional Africa, we do not marry only wives but also their family members. This implies that a man marrying from a family will help the family members because they are part of his family not because he is innately charitable. A man feeds and train his children not because he is charitable but because he sees it as his duty. In a polygamous union, this duty is extended to other members of the family and thereby the wealth is circulated. Polygamy served a purpose in traditional Africa. Its abolishment in Christian societies has been a curse rather than a blessing.

Rejection of Polygamy also affects the Church negatively: The abolition of polygamy is not only disadvantageous to the people and the society, but it also puts Christianity in a disadvantageous position as regards other religions. Polygamy leads to more children, which means the Islamic religion that allows this is likely to dominate the world in the nearest future. If the Muslims understand, that in 50 years, they will be more in number than Christians, they would understand, that the violent fight to enthrone Islam is needless. Islam will become a state religion in many countries soon if the present one man one wife policy continues in Christianity. The one-man one wife doctrine raises cases of abortion and infertility amongst Christian societies, thereby making their population not to grow in 
comparison to the Islamic societies. The one-man one wife doctrine is a shot at the leg of Christianity by Christianity itself.

It leads to prolonged Singlehood: The one-man one wife doctrine has made many to remain single longer than expected. Christianity has imbued the belief that God has created one wife and one husband for each person. Many people spend almost all their entire lives attempting to find this God intended wife or husband. Many marriage proposals have been rejected, many planned marriages failed, due to the belief that the proposed husband or wife is not the 'missing rib'. Most people have wasted almost all their lives praying and fasting for God's intended spouses for them. This search for a wife carved out from the rib of a man, has remained disappointing for most men and women, making them prolong their singlehood. In polygamy, one marries a wife not because she is fashioned by God for him, but because he likes her. This wait for God's approval was absent and thus marriage was quicker and less laborious.

Aside from the influence of the 'missing rib' belief, monogamy instigates most men to delay marriages out of over carefulness. When one is entitled to only one thing, it is natural for that person to take his time to select the best, especially in this case that divorce is not allowed. Monogamy makes most men to over scrutinize before marriage. This over scrutiny leads to delayed marriages and sometimes no marriage at all. In polygamy, this over scrutiny is not the case, as the defect of one wife, could be remedied by another wife. In polygamy, therefore, weaknesses in women are more tolerated and the process of marriage less tedious and rigorous. This tolerance in polygamy, makes divorce (which is a common feature of monogamy) to be rare.

Polygamy breeds happiness: With polygamy, almost all the singles ladies desiring marriage will find a husband (MacQueen 2007). This will end social ills and crises that are occasioned by snatching of people's husbands, abortion and course promiscuity. The oneman one wife policy has left a lot of women in a perpetual search for a husband. To some this search has led to trauma. With polygamy, there will be no room for this, which means more women will live happier and more fulfilled lives. The cases of abortion will also drastically reduce, as most of these abortions are a result of not wanting to have a baby for another woman's husband or not wanting to born out of wedlock. In short, abortion will be reduced to a minimum, for if there are few unmarried people (this could be made possible by polygamy), only a few abortions will be occurring. Abortion is mostly carried out by single women, and the more the singles, the more the likelihood that abortion will be carried out. Reduction in abortion will reduce cases of infertility (Witte 2007). Infertility which has been on the increase today in Africa is mostly due to unsafe abortions. Thus, due to its ability to provide greater happiness to a greater number, by Bentham's standard, polygamy is good.

\section{ARGUMENTS AGAINST POLYGAMY AND RESPONSES}

One serious criticism that could be leveled against polygamy is its penchant to lead to family crisis - it most times pitch the wives or their children against themselves. This could be true but is highly dependent on the way the family is run by the man. It is also depended on the societal conception of polygamy. In traditional African societies, where polygamy was seen as normal, it was easy for women to tolerate and accommodate themselves as co-wives. Such rancour was not common in traditional polygamous homes. 
It has become more difficult for women to tolerate polygamy today, because of the widespread Christian teaching against it, this intolerance is the root cause of the crisis in contemporary polygamous homes. It is not polygamous itself that leads to crisis, it is the change in belief. In Muslim homes, where the belief is still intact, crises are seldom heard of. Other causes of the crisis in polygamous homes are not distinct from the ones that cause the crisis in monogamous homes; the extra crisis that occurs in polygamous homes comes from intolerance that is occasioned by a change of beliefs, thanks to Christianity.

The feminists are actually right in their claim that polygamy is a kind of subjugation of the womenfolk (Uduigwomen \& Edet 2004). In fact, the soundest argument against polygamy is its subjugation of the women - the treatment of women as unequal to men. The feminist will argue here that women should also be allowed to marry more than one husband if polygamy has to stand. As sound as this argument is, it has remained lip service. Almost all Christian women today profess a belief in monogamy as enshrined in the teachings of Christianity and thus resist polygamy with all their might. Ironically, however, they still cling to polygamy indirectly. We see them every day running after married men and having affairs with them. Is this not a sign that their resistance to polygamy is just an outward show? They denounce polygamy on one hand and on the other hand engage in extra-marital affairs. She resists polygamy on one hand and at the same time accepts sexual advances from married men. From my own reasoning, we think Africans inwardly want polygamy but outwardly denounces it just to please the church's leaders.

One other strong criticism against polygamy is that it leads to much poverty. Those who hold this view, argue that polygamy was right in traditional Africa, because of the need for more labourers on the farm. For them, today such a large number of children are no longer needed, for it is now more expensive to raise children. Children today are expected to get a decent formal education, which will be too burdensome for parents with many of them. We acknowledge the strength of this argument, but we believe, polygamy has never been mandatory even in traditional Africa and need not be compulsory now. It should be left optional for those who can cope with its contemporary challenges.

\section{EVALUATION AND CONCLUSION}

There are many advantages of polygamy both to individuals and society. These benefits will have been the portion of the society, but not for the teachings of Christianity. We believe that Christianity should change this doctrine. It should be made optional. Even in the days where polygamy was legitimate, not everybody married more than one. Even if it is made legitimate again, it would not necessarily be obligatory for all to be polygamous. Those who chose to embrace it should not be demonized, ostracized and condemned by the church. The men of God like David, Solomon, Moses, and the rest who married more than one wife, were not rebuked by God at any place in the Bible. God even rebuked David when he took Uriah's wife saying we gave you many wives, if you wanted more you should have told me (2 Samuel 12:8). This means that God approved of his many wives. He only frowned at the sexual immorality he committed. God frowns at the sexual immorality that married people commit, that is why more wives should be allowed so that this will reduce to the barest minimum. We are not a theologian or a scripture scholar, thus we acknowledge the fact that we may be wrong in my attempt to justify polygamy using the scripture. Where we know, we are not wrong is the fact that God sometimes allows 
people to retain their traditions alongside Christianity even when it goes against biblical teachings (Bisong 2020).

This is exemplified in the first council of the church, where the church ruled against circumcision in favour of the Gentile converts to Christianity. This is against the biblical passage that reads: "Any uncircumcised male, who has not been circumcised in the flesh, will be cut off from his people; he has broken my covenant" (Genesis 17:8). Circumcision and most other mosaic laws were knocked off for the new Gentile convert in Acts 15, to enable them to fit well into Christianity. Some of the African traditions ought to have been allowed to stand, because of their utilitarian value - one of these is polygamy.

What we think is that Christianity should be fashioned in a way that human beings will be made, freer to live out their nature to the fullest. Christianity should be re-rooted in African cultures. We wonder why African traditions are so abhorrent to the church that, Christianity cannot be built on them like it was in the early church in the days of the apostles. By attempting to set aside African long-held traditions, Christianity only succeeded in shooting itself in the foot. It has succeeded in producing Christians who are not really Christians, but what we call Pseudo-Christians. Most Africans who claim to be Christians today, are only stage-showing, inwardly they are something else. They profess Christianity with their lips, dresses, appearances and associations but in mind are far from Christianity - they fail to live like Christians. Christianity in contemporary times is marked by the double standard - they profess a belief in Christ on one hand and on the other hand do the opposite. This is large as a result of early missionaries failing to root Christina doctrines in traditional Africans values.

\section{REFERENCES}

Anna, M., Hazel, A., \& Josegh, K. (2020). Christian Teachings on Marriage and Its Impact on Customary Marriage among the Iteso of North Teso. Journal of Education Science, 5(4), 257-266.

Bentham, J. (1981). "An Introduction to the Principles of Morals and Legislation". www.utilitarianism.com/jeremy-bentham/index.html.

Bisong, P. B. (2020). The Catholic Church. Her Structure and Belief-System. Germany: GRIN Verlag.

Edet, M. (2003). A Case for the Abolition of Capital Punishment in Nigeria. Ndunode: Calabar Journal of Humanities, 137-150.

Edet, M. I. (2018). Women in the His-story of Philosophy and the Imperative for a 'Herstorical'Perspective in Contemporary African Philosophy. In African Philosophy and the Epistemic Marginalization of Women (pp. 155-166). Routledge.

Gyekye, K. (1996). African Cultural Values: An Introduction. Accra: Sankofa Publishing Company.

Kiyimba, A. (2011). "The domestic relations bill” and inter-religious conflict in Uganda: A muslim reading of personal law and religious pluralism in a postcolonial society. In Displacing the State: Religion and Conflict in Neoliberal Africa (pp. 240-280).

MacQueen, K. (2007). Polygamy: Legal in Canada. Maclean's, 120(24), 16. http://ezproxy.lib.ucalgary.ca/login?url=http://search.ebscohost.com/login.aspx?dir ect $=$ true $\& d b=$ flh $\& A N=$ MRB-FSD0903-000118\&site=ehost-live

Ojukwu, W. I. (1995). Presenting Christian marriage to youth within a polygamous Nigerian culture. In ProQuest Dissertations and Theses. https://search.proquest.com/docview/304173948?accountid=13042 
http://oxfordsfx.hosted.exlibrisgroup.com/oxford?url_ver=Z39.88-

2004\&rft_val_fmt=info:ofi/fmt:kev:mtx:dissertation\&genre=dissertations+\%26+th eses\&sid=ProQ:ProQuest+Dissertations+\%26+Theses+Glob

Omoregbe, J. (1979). Is polygamy incompatible with Christianity. AFER, 2l(6), 363. http://gaba-publications.org/ (Publisher's http://search.ebscohost.com/login.aspx?direct=true \&db=rfh\&AN=ATLA00007747 30\&site=ehost-live

$\mathrm{Pu}, \mathrm{R}$. (2017). An analysis on biblicat marriages and related ethics. International Journal of Sino-Western Studies, 12, 59-69.

Rongjian, P. (2017). An Analysis on Biblical Marriages and Related Ethics. INTERNATIONAL JOURNAL OF SINO-WESTERN STUDIES, 12, 59-69.

Uduigwomen, A. F., \& Edet, M. I. (2004). The primacy of the family in the philosophies of Confucius and Aristotle, and in African philosophy: A comparative analysis. Sophia: An African Journal of Philosophy, 7(1), 83-89

Witte Jr, J. (2014). The Nature of Family, the Family of Nature: The Surprising Liberal Defense of the Traditional Family in the Enlightenment. Emory LJ, 64, 591.

Witte, J. (2003). Church, State, and Marriage: Three Reformation Models. Word \& World, 23(1), 40-47. $\quad$ https://wordandworld.luthersem.edu/content/pdfs/231_Defining_Marriage/23-1_Witte.pdf 